\title{
The Effect of the Use of Picture Story Book Based on Scientific Approach toward the Problem Solving Skill of Primary School Students
}

Khoirunnisa

Yogyakarta State University

Student of Primary Eeducation

Yogyakarta, Indonesia

khoirunnisa_pgsd@yahoo.co.id
Pratiwi Pujiastuti

\author{
Yogyakarta State University \\ Lecturer Primary Eeducation \\ Yogyakarta, Indonesia \\ pratiwi@uny.ac.id
}

Zuhdan Kun Prasetyo

\author{
Yogyakarta State University \\ Lecturer Primary Eeducation \\ Yogyakarta, Indonesia \\ zuhdan@uny.ac.id
}

\begin{abstract}
In the $21^{\text {st }}$-century, education requires that every student masters various skills, intelligence, and character to support future success. Therefore, the learning process and learning resources must ensure students to have these skill, especially critical thinking skill in solving problems. However, the observation results show that many schools have not been able to facilitate learning resources to develop these skill. This study aimed to analyze the effect of the picture storybook based on a scientific approach on students' problem-solving skill. The research method was quasiexperiment with pre-test post-test control group design. The research population was the fourth-grade elementary school students in Mlati District, Sleman, Yogyakarta. Data were collected by giving the equivalent pre-test and post-test questions. The results show that the use of the picture storybook based on a scientific approach had a positive and significant effect on the problem-solving skill of fourth-grade elementary school students. It also proved that the storybook was more effective as a learning source to improve problemsolving skill of fourth-grade elementary school students compared to existing textbooks. Nearly all students were enthusiastic and eager to use the storybook in the learning process.
\end{abstract}

Keywords - picture story book, scientific approach, problem solving skill

\section{INTRODUCTION}

Education is a form of manifestation of dynamic human culture and the requirement of development and change. Changes regarding education improvement at all levels need to be continuously done in anticipation of future interests. Moreover, the change should be adapted to the $21^{\text {st }}$-century demand that requires every individual to master various skill, intelligence, and character to support future success. The learning process must ensure students to have the skill to learn and innovate, including critical thinking skill and problem-solving, communication and collaboration, creativity and innovation, skill in using media, information, and technology, and the ability to have a quality career [1]. This means that education is essential for human to compete and to face the future.

One effort of the government to improve the education system is the implementation of the 2013 Curriculum. The 2013 Curriculum, with its scientific approach, is expected to facilitate students to have the skill to learn and innovate as demanded in $21^{\text {st }}$ century learning. This success will be indicated by the learning process that successfully achieves the predetermined objectives. However, a quality learning process requires many supporting factors, such as harmony between each learning component. Another supporting factor is the use of learning resources that are in accordance with the students' needs and characteristics and meet the curriculum standard. The selection and use of these learning resources are essential because the book, as a learning source, should help the students to obtain the important information during the learning process [2]. The ultimate goal of the use of this learning book is to deliver the subject effectively, maximally, and comprehensively to improve various skill essential for the students' future.

The curriculum is developed with a scientific approach that provides special books for the students. The books are designed to meet the learning objectives but they do not make the effective learning process and do not facilitate students to think critically in problem-solving. This is caused by the fact that the book has not been developed in accordance with the characteristics of elementary school students who are very interested in books that are colorful with many illustrations, not only words. This problem influences the low ability of students' critical thinking in problem-solving, which is indicated by the low students' learning outcomes in the problem-solving assignments. The materials in the 2013 Curriculum textbook also are not adapted to the student's surroundings. Whereas a learning book 
should consider the students' characteristics. In Piaget's theory, the elementary school students are in the concrete operational category that deals with problems logically from the actual events in their surroundings [3].

One way to overcome the problems is by using a picture storybook that is in accordance with the students' characteristics [4]. The picture storybook is developed with a scientific approach and the problem-based learning method (in accordance with the 2013 Curriculum). The use of this book is essential to facilitate the concrete learning process for the students. Hamalik [5] states that a concrete learning process is supported by images that facilitate the visual activities, such as reading and others. Thus, the solution proposed in this study to solve the low problem-solving skill of elementary school student was the implementation of a picture storybook based on a scientific approach with a problem-solving method.

The picture storybook is a book that conveys the information in two ways: texts and the illustrations of drawings, which are closely related to each other [6, 7]. The images cover the lack of language so that information can still be understood by elementary school students with their simple language skill [8]. The development of this storybook uses the scientific approach stages of observing, questioning, gathering information, associating, communicating, and networking $[9,10]$. It is designed in such a way that students are actively constructing their own concept, laws or principles [11].

The picture storybook is also a result of theoretically-tested and valid development based on the judgment of linguists, media experts, and material experts. It is strongly recommended to be used as a learning resource for elementary school students. However, the implementation of the storybook also requires several supporting factors, such as principals, professional teachers, conducive school climate, complete supporting facilities and infrastructure to develop a quality learning process. The implementation also should consider the inhibiting factors, such as the student admissions system that is not according to the standard, there are some students cannot read and write, the inappropriate assessment instrument, the limited learning hours, and the teachers that give too many materials to the students in the learning process. The proper implementation of the storybook is expected to develop the students' thinking and learning process [12].

Furthermore, to address the problem of low students' problem-solving skill, the picture storybook is developed with an appropriate method, which is problem-based learning (PBL). This method is also one of the most widely adopted methods to support a student-centered learning approach and empower the students [13]. This method directs and motivates students to develop and acquire the knowledge by using the problem-solving process [14]. The problems described in a story with illustrations of pictures of the students' surroundings will make the learning more effective, the students become more active and independent. To develop students' selfevaluation, interpersonal communication, and critical thinking, the learning process should be implemented in teams or groups $[9,15,16]$. The steps of the PBL method developed in this illustrated storybook include 1) student's orientation to the problem, 2) organizing students for the learning process, 3) guiding individual and group investigations, 4) developing and presenting the work, and 5) analyzing and evaluating the troubleshooting process [11]. If these steps are appropriately implemented, the students should develop critical thinking skill in problem-solving; thus, the students not only think of something concrete but also abstract and complex ideas. This means that the learning indirectly influences the students to learn to solve a problem using their existing knowledge or seeking required knowledge that they do not yet have [17].

Problem-solving is an action that is first performed when faced with a problem. It involves several skill that a person must perform: high-level thinking skill such as visualization, association, thinking abstraction, understanding, manipulation, reasoning, synthesis analysis, and generalizing everything that needs to be managed and coordinated (Garofalo \& Lester [18]). Some of these skill will develop behaviors that lead to solutions and processes involving manipulation or operations on prior knowledge defined as problem-solving (Funkhouser \& Dennis [18]).

This skill requires a lot of information for students, which requires a learning resource that facilitates them in solving problems to get the right solution, not just using cognitive, concepts, or procedures alone [19]. In addition, there are several processes that must be done to solve the problem properly, which are 1) problem awareness; 2) explaining and defining the problem; 3) seeking relevant information; 4) formulating possible solutions or plans; 5) evaluating possible solutions; 6) checking the obtained solution; 7) accepting the solution [20, 21].

Through these processes, we developed problemsolving indicators to measure the problem-solving ability of fourth-grade elementary school students. The indicators developed in this study were adjusted to meet the materials and learning objectives, which was compiled in a picture storybook based on a scientific approach with the PBL method, and the ability of fourth-grade elementary school students, including 1) identifying the problem, which is the early stages of the students in determining the problems by arranging the knowledge from their observation to formulate the problems; 2) defining and 
describing the problem, i.e. the stage where the students analyze the existing problems by determining the cause and the consequences of the problem that will be used as a reference in formulating and determining the right solutions to the problem; 3) exploring possible strategies, which is the final stages where the students formulate and determine the appropriate solution.

\section{METHODS}

The method used in this research was the quasiexperiment with nonequivalent pre-test and post-test control group design. The sampling collection technique was the simple random sampling. This study used two classes as the experiment and the control. The experiment class used storybooks based on a scientific approach and the control class used the 2013 Curriculum textbook.

The study design was developed from McMillan and Schumacher's study [22], which can be seen in Table 1. The questions in the pre-test and post-test were equivalent.

TABLE 1. RESEARCH DESIGN

NONEQUIVALEN PRETEST AND POSTTEST CONTROL GROUP DESIGN

\begin{tabular}{|c|c|c|c|}
\hline Group & Pretest & Treatment & Posttest \\
\hline Group 1 & $\mathrm{O}_{1}$ & $\mathrm{X}_{1}$ & $\mathrm{O}_{2}$ \\
\hline Group 2 & $\mathrm{O}_{1}$ & $\mathrm{X}_{2}$ & $\mathrm{O}_{2}$ \\
\hline
\end{tabular}

Informations

$\mathrm{O}_{1}$ : Pretest

$\mathrm{O}_{2}$ : Posttest

$\mathrm{X}_{1}$ : Learning by using picture book based on scientific approach

$\mathrm{X}_{2}$ : Learning by using 2013 curriculum

Each class had 29 students. The data was collected using the test technique with equivalent questions before and after the treatment. The questions were the problem-solving type, which was developed in accordance with the indicators of problem-solving skill. The topic of the questions was the solutions to environmental issues surrounding the students, which was derived from Theme 8 of the textbook, "Lingkungan Tempat Tinggalku". The results of the pre-test and post-test were calculated and analyzed using SPSS 23 for Windows. The study used two variables: independent and dependent variables. The independent variable was the picture storybook based on a scientific approach while the dependent variable was the problem-solving skill of fourth-grade elementary school students.

The problem-solving questions were declared valid and reliable. The content validation was done by the experts and the construct validation was assessed with an initial test on a class outside the research subject. After the validity was obtained, the reliability of the problem was then tested. In this study, the assumption tests included the normality and homogeneity tests, before the hypothesis test was conducted. The result shows that the data were normal and homogeneous. The hypothesis test was done by using ANOVA to assess whether there is a mean difference between the experimental and the control groups.

\section{RESULT AND DISCUSSION}

The descriptive analysis results of the pre-test mean of experimental class students who used the storybook and control class students who used the 2013 Curriculum textbook are shown in Table 2.

TABLE 2. STATISTIC RESULT OF PRETEST IN EXPERIMENTAL CLASS AND CONTROL CLASS

\begin{tabular}{|l|c|c|}
\hline \multicolumn{1}{|c|}{ Description } & Experimental Class & $\begin{array}{c}\text { Control } \\
\text { Class }\end{array}$ \\
\hline $\mathrm{N}$ & 29 & 29 \\
\hline Mean & 52 & 52 \\
\hline Median & 52 & 55 \\
\hline $\begin{array}{l}\text { Deviation } \\
\text { Standard }\end{array}$ & 7.2 & 7.3 \\
\hline Minimum Score & 41 & 41 \\
\hline Maximum Score & 73 & 75 \\
\hline Sum & 1496 & 1536 \\
\hline
\end{tabular}

The results of the descriptive analysis show that the pre-test mean of the control class was higher than the experiment class. This means that students' initial ability to solve problems in the control class was better than the experiment class. The initial knowledge determines that the initial score can help or hinder the new knowledge to be given [23]. Students with better initial knowledge usually also have a good understanding and memory of learning compared to students with less initial knowledge. However, the mean difference in each elementary school was not significant. Therefore, the mean of the initial problem-solving skill of each class was nearly equivalent. This means that the sample of this study could build and find the meaning in constructing his own knowledge by applying it to the problem of active problem-solving in the learning but they had not achieved maximum results.

The comparison results of the problem-solving skill of experimental class students who used the storybook and control class students who used the 2013 Curriculum textbook are shown in Table 3.

TABLE 3. STATISTIC RESULT OF POSTEST IN EXPERIMENTAL CLASS AND CONTROL CLASS

\begin{tabular}{|l|c|c|}
\hline \multicolumn{1}{|c|}{ Description } & Experimental Class & Control Class \\
\hline $\mathrm{N}$ & 29 & 29 \\
\hline Mean & 82 & 67 \\
\hline Median & 82 & 66 \\
\hline $\begin{array}{l}\text { Deviation } \\
\text { Standard }\end{array}$ & 7.1 & 9.8 \\
\hline Minimum Score & 66 & 41 \\
\hline Maximum Score & 93 & 91 \\
\hline Sum & 2375 & 1938 \\
\hline
\end{tabular}

The post-test score of students' problemsolving skill in the experiment class was higher than the pre-test mean score. Likewise, the control class also experienced an increase in the post-test mean 
score. However, there was a large mean difference between each class. The mean of the experiment class rose from 52 to 82 while the mean of the control class only increased from 53 to 67 . The increase difference is displayed in Figure 1.

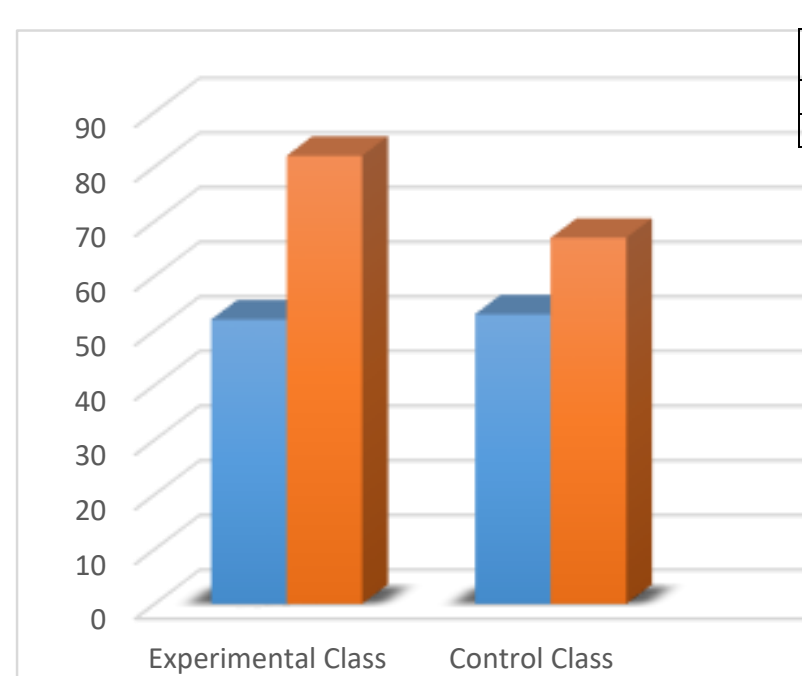

Experimental Class

Control Class
Meanwhile, the homogeneity test of pre-test and post-test variance of problem-solving skill was done by using the Levene test, with the results are shown in Table 5.

TABLE 5. HOMOGENITY TEST RESULT

\begin{tabular}{|l|c|r|c|}
\hline \multicolumn{2}{|c|}{ Levene Statisic } & Sig. & Cunclusion \\
\hline Pretest & 0.113 & 0.893 & Homogen \\
\hline Postest & 1.214 & 0.302 & Homogen \\
\hline
\end{tabular}

The Levene test results show that the significance of pre-test problem-solving skill was 0.893 , which was larger than 0.05 ; therefore, the variance was considered homogeneous. Meanwhile, the significance of post-test problem-solving skill was 0.302 , which was also larger than 0.05; thus, the variance was also considered homogeneous.

After proving that the data were normal and homogenous, then the hypothesis was tested by using ANOVA test to analyze whether the storybook has a positive and significant effect on problem-solving skill or not, with the results can be seen in Table 6 .

TABLE 6. ANOVA RESULT

\begin{tabular}{|c|c|c|c|}
\hline $\begin{array}{c}\text { Dependent } \\
\text { Variable }\end{array}$ & \multicolumn{3}{|c|}{ The Posttest Data of Problem Solving Skill } \\
\hline & F & Sig. & Conclusion \\
\hline $\begin{array}{c}\text { Problem } \\
\text { Solving Skill }\end{array}$ & 20.375 & 0.000 & $\mathrm{H}_{\mathrm{O}}$ is rejected \\
\hline
\end{tabular}

The ANOVA results show that the $F_{\text {Calc }}$ was 20.375 and the significance was 0.000 , which were lower than 0.05 . This means that $\mathrm{H}_{0}$ was rejected or the storybook has a positive and significant effect on the problem-solving skill of fourth-grade elementary school students. The post-test mean comparison also shows that the mean of the experiment class value was higher than the control class, with the numbers were 82 and 67 respectively. This proves that the storybook was more effective at improving the problem-solving skill of fourth-grade elementary school students compared with the 2013 Curriculum textbook.

The effectiveness is influenced by the fact that the storybook is more suitable for the elementary school students who are in the concrete operational phase, which require the learning to be accompanied by the real or concrete things. The presence of stories along with the pictures makes students get a real experience of the taught subject and develop students' cognitive, affective, or psychomotor aspects [7]. The illustration further adds the students' learning interest [24], which is characterized by a higher motivation and a more enthusiastic attitude of reading [25] as well as a passion for working on problem-solving. Compared to ordinary books with little or no pictures, the picture storybooks are more complex for students, more challenging, and make students more provocative in learning [26].

The storybook used in this study was developed with the problem-based learning method to assist 
students in solving problems according to the problem-solving stage by developing thinking and problem-solving skill [9]. Improvement of problemsolving skill is also influenced by the scientific approach used in the storybook. The approach indirectly guides students to improve their intellectual ability, especially the ability of high-level thinking to solve a problem, which leads to a significant increase in students' problem-solving skill $[9,27]$.

The use of problem-based learning method also provides an improvement to the science and cognitive outcomes of elementary school students. Rogal et al. $[14,15,16]$ state that to improve problem-solving skill, students must be stimulated with solving the real problem through problem-based learning. In addition, this learning method can also train students to conduct research, integrate theory and practice, apply the knowledge and skill to develop feasible solutions to problems [28] and make students more responsible for their own learning process [29].

Student-solving skill need to be developed and integrated into all subjects, or by allocating extra time explicitly. The problem-solving skill should be taught to elementary school students [30]. The use of a picture storybook based on a scientific approach with problem-based learning method can facilitate students to improve critical thinking skill in solving a problem to obtain the knowledge in the form of a solution of the existing problems. The use of the storybook was more effective than the existing textbooks. Students were also very interested in the storybook during the learning process. This indirectly makes a quality and independent learning process because it allows students to build teams or groups to solve problems that have been adapted to the problems that exist in their surrounding environment.

\section{CONCLUSION}

The results show that the use of a picture storybook based on a scientific approach had a positive and significant impact on students' problemsolving skill. In addition, the storybook was more effective than the 2013 Curriculum textbook. It can be concluded that the picture storybook based on a scientific approach is highly recommended to be used as a learning material. The storybook improved students' motivation and enthusiasm for learning as evidenced by the increase in the students' problemsolving skill. This is caused by the fact that the picture storybook was tailored to the characteristics of elementary school students who are in the concrete operational phase and also in accordance with the curriculum that is a scientific approach with problembased learning method; thus, it improved students problem-solving skill through stories with interesting pictures.

\section{ACKNOWLEDGMENT}

Researchers give many thanks to all partners in this research: Dr. Pratiwi Pujiastuti, M.Pd. and Prof. Dr. Zuhdan Kun Prasetyo, M.Ed. as a thesis supervisor who gave a lot of criticism and suggestions in this study. Especially thanks to Lembaga Pengelola Dana Pendidikan (LPDP)/ Indonesian Endowment Fund for Education for giving me full scholarship to pursue study in Applied Education Faculty, Graduate School, Yogyakarta State University, Indonesia. All friends in this research. Thank you so much for many help. And all the student I care about.

\section{REFERENCES}

[1] B. Triling, and C. Fadel, 21st Century Skill: Learning For Life in Our Times. Hoboken: Jossey-Bass, 2009.

[2] S. R. Yunus, and I. G. M. Sanjaya. B. J., "Jurnal Pendidikan IPA Indonesia.” Jurnal Pendidikan IPA Indonesia, vol. 2, pp. 203-208, 2013.

[3] D. H. Schunk, Learning Theories: An Educational Perspective Learning. Yogyakarta: Pustaka Pelajar, 2011.

[4] N. Tucker, The Child and The Book. Australia: Cambridge University Press, 1981.

[5] O. Hamalik, Proses Belajar Mengajar. Jakarta: PT Bumi Aksara, 2013

[6] C. S. Huck, S. Hepler, and J. Hickman. Children's Literature in The Elementary School. New York: Holt, Rinehart and Winston , 1987

[7] D. Mitchell, Children's Literature, An Invitation Tom the World. Boston: Ablongman, 2003.

[8] B. Nurgiyantoro, Sastra Anak Pengantar Pemahaman Dunia Anak. Yogyakarta: Gadjah Mada University Press, 2013.

[9] Daryanto, Pendekatan Pembelajaran Saintifik Kurikulum 2013. Yogyakarta: Gava Media, 2014.

[10] R. S. Abdullah, Pembelajaran Saintifik Untuk Implementasi Kurikulum 2013. Jakarta: Bumi Aksara, 2014.

[11] Hosnan, Pendekatan Saintifik dan Kontekstual dalam Pembelajaran Abad 21: Kunci Sukses Implementasi Kurikulum 2013. Bogor: Ghalia Indonesia, 2014.

[12] A. Machin, "Implementasi Pendekatan Saintifik, Penanaman Karakter dan Konservasi Pada Pembelajaran Materi Pertumbuhan”. Jurnal Pendidikan IPA Indonesia, vol. 2, pp. 203-208, 2013

[13] M. T. Amir, Inovasi Pendidikan Melalui Problem Based Learning. Jakarta: Kencana, 2015.

[14] S. M. M. Rogal, and P. D. Snider, "Rethinking the lecture: The Application of Problem Based Learning Methods to Atypical Contexts." Nurse Education in Practice, vol. 8, pp. 213-219, 2008

[15] T. A. Yen, "The Integration of Problem-Based Learning (PBL) and Action Learning in Higher Education of Taiwan." Ke Cheng Yan Jiu Journal of Curriculum Studies, vol. 10, pp. 51-69, 2015.

[16] K. S. Chunta, and E. D. Katrancha, "Using Problem-Based Learning In Staff Development: Strategies For Teaching Registered Nurses And New Graduate Nurses." Journal of Continuing Education in Nursing, vol. 41, pp. 557-564, 2010.

[17] Kemendikbud, Lampiran Permendikbud Nomor 81a Tahun 2013 tentang Implementasi Kurikulum Pedoman Umum Pembelajaran. Jakarta: Kementerian Pendidikan dan Kebudayaan RI, 2013. 
[18] R. Foshay, and J. Kirkley, Principles for Teaching Problem Solving. Minnesota: Plato Learning, 2003.

[19] M. Montague, C. Enders, and S. Dietz, "Effects of Cognitive Strategy Instruction on Math Problem Solving of Middle School Students with Learning Disabilities." Learning Disability Quarterly, vol. 34, pp. 262-272, 2011.

[20] R. M. Gorman, The Psychology of Classroom Learning. Columbus: Ohio Company, 1974.

[21] J. W. Santrock, Psikologi Pendidikan. New York: McGrawHill, 2011.

[22] J. H. McMillan, and S. Schumacher, Research in Education: Evidence-Based Inquiry $17^{\text {th }}$ ed. Upper Saddle River: Pearson, 2010.

[23] R. A. Thompson, and B. L. Zamboanga, "Academic Aptitude and Prior Knowledge as Predictors of Student Achievement in Introduction to Psychology." Journal of Educational Psychology, vol. 96, pp. 778-784, 2004.

[24] S. Hsiu-Chih, "The value of English picture story books". ELT Journal, vol. 62, pp. 51, 2008.

[25] A. Baird, et al., "Child Readers And The Worlds Of The Picture Book." Children's Literature in Education, vol. 47, pp. 14, 2016.

[26] W. T. Owens, and S.N. Linda, The Social Study. More than Just Pictures: Using Picture Story Book to Broaden Young Learners Social Consciousness. UK: Routledge, 2014.
[27] C. Setyaningrum, Pengembangan Buku Cerita Bergambar Berbasis Pendekatan Saintifik dengan Metode PBL untuk Meningkatkan Rasa Ingin Tahu dan Kemampuan Pemecahan Masalah Siswa Kelas IV SD, Yogyakarta, Universitas Negeri Yogyakarta. Master of Education, August 2017.

[28] Savery, "Overview of PBL: Definitions and Distinctions." Interdisciplinary Journal of Problem-Based Learning, vol. 1, pp. 9, 2006.

[29] C. E. Hmelo-Silver, \& H. S. Barrows, "Interdisciplinary Journal of Problem-Based Learning Goals and Strategies of a Problem-based Learning Facilitator Goals and Strategies of a Problem-based Learning Facilitator." Interdisciplinary Journal of Problem-Based Learning The Interdisciplinary Journal of Problem-Based Learning @BULLET, vol.1, pp.24, 2006.

[30] S. Rufaida, and E. H. Sujiono, "Pengaruh Model Pembelajaran dan Pengetahuan Awal terhadap Kemampuan Memecahkan Masalah Fisika Peserta Didik Kelas XI MAN 2 Model Makassar.” Jurnal Pendidikan IPA Indonesia, vol. 2, pp.161-168, 2013. 